\title{
OUTCOME-BASED EDUCATION FOR ENGLISH TEACHING REFORM IN THE ERA OF THE “POST-METHOD”
}

\author{
Ma Yan ${ }^{1}$, \\ Zhang Shuyue ${ }^{2 \mathrm{i}}$ \\ ${ }^{1}$ Associate Professor, \\ School of Foreign Studies, \\ Yangtze University \\ Hubei Province, 434000, \\ P. R. China \\ ${ }^{2}$ School of Foreign Studies, \\ Jingzhou College \\ Hubei Province, 434000, \\ P. R. China
}

\begin{abstract}
:
"Post-method" language education is a new trend in foreign language teaching after the "method era". "Outcome-based Education (OBE)" is an important theory for students' learning development because it is students-centered and focuses on students' performance. Combining the Post-method teaching system, and based on the OBE concept, we aim to explore the reforms of college English in the Post-method teaching era. We discussed the characteristics of teachers and students under the concept of OBE and analyzed the ways to carry out OBE in college English teaching. We hope that it will go beyond the limitations of traditional Chinese college English teaching theory and practice and bring new insights into college English teaching reforms.
\end{abstract}

Keywords: post-method teaching, OBE, college English teaching

\section{Introduction}

As far as foreign language teaching methods are concerned, linguists have been making unremitting efforts in the past few hundred years to seek an ideal foreign language teaching method applicable to improve students' different language skills, including reading, writing, speaking, listening and translating. Some influential teaching methods were proposed, such as Translation Method in the 16th century, Direct Method in the mid-19th century, Audio-lingual and Audio-visual approach in the 1940s and the 1950s, Cognitive Approach Method, Silence Way, Community Learning Method, and Suggestiopedia in the 1960s, Total Physical Response, Natural Approach, Communicative Approach in the 1970s, Task-based Approach, Content- 
based Approach, and the Immersion Approach in the 1980s. Although these teaching approaches and methods in the era of "methods" have played a positive role in English teaching, there are inevitably various defects and deficiencies because they cannot fundamentally solve the problems of "high input but low output" in English teaching. At the same time, the teaching filed has already had a skeptical attitude towards the idea of sticking to a certain teaching method or mode. Educators became gradually aware that there is no best language teaching method, and it is impossible to find a universal teaching method for all teaching problems. Therefore, in the 1990s, the notion of methods has been questioned by more and more experts. When talking about the effects of the existing teaching methods, English applied linguist Allwright (1991) considered them helpless and summed up six reasons. Later, he declared that the methods had died. American scholar Brown (2002) used the metaphor of "death" to indicate the uselessness of methods. This criticism of and doubt about methods urged many scholars to find a new way out for language teaching, so the "Post-method" era of English teaching came.

In recent years in China, with the rapid development of mobile Internet technology, a variety of intelligent learning platforms continue to appear, where the text has become diversified, multimodal and multilingual. Therefore, the practicing of a single teaching method has obviously failed to meet the development and needs of the new age (Liu, 2008), which also leads to the transformation of foreign language teaching from "the Method era" to "the Postmethod era". "Post-method" teaching helps college English teachers rid themselves of their dependence on a unified teaching method. Thus, they can design their teaching based on their deep reflection on the teaching environment, teaching rules, teaching models and students' needs and feedback and make an innovative breakthrough in the theory and practice of college English teaching (Rao and Ji, 2014).

\section{Theoretical Basis of "Post-method"}

Kumaravadevilu (2003: 32), the founder of "Post-method" education, pointed out that "Postmethod" does not mean any specific teaching method; instead, it is "an alternative to method" guiding foreign language teaching from a macro-perspective. "Post-method" teaching is not the rebellion and deviation of traditional language teaching methods, but the inheritance, transcendence and development of all specific teaching methods, and an alternative to the deficiencies of the traditional teaching as well. Kumaravadevilu regarded teaching theory as a system centered on teachers' autonomous behavior, with three parameters in it:

1) A pedagogy of particularity. Language pedagogy, to be relevant, must be sensitive to a particular group of teachers teaching a particular group of learners pursuing a particular set of goals within a particular institutional context embedded in a particular sociocultural milieu (Kumaravadivelu, 2001: 538). Foreign language teaching should inherit, integrate, develop and innovate their teaching methods with the consideration of the specific context, so as to achieve the good effect of foreign language teaching.

2) A pedagogy of possibility. It refers to the fact that different social status, economic and political backgrounds make the classroom a place where different ideologies, cultures and social forms collide with each other. In foreign language teaching, we should be sensitive 
to social politics, lay emphasis on students' personal identity and subjectivity, cultivate their social and political awareness and help them maintain their cultural identity under the influence of foreign cultures.

3) A pedagogy of practicality. It refers to teacher-generated theory of practice that has a direct impact on language teaching. No theory of practice can be useful and usable unless it is generated through practice (ibid: 541). A pedagogy of practicality can ensure the interaction between teaching theory and practice and avoid the disadvantages of the dichotomy of theory and practice.

At the same time, Kumaravadevilu (2003) formulated a macro-strategic framework, based on which teachers can conduct their specific teaching scenario: 1) Maximize learning opportunities; 2) Minimize perceptual mismatches; 3) Facilitate negotiated interaction; 4) Promote learner autonomy; 5) Foster language awareness; 6) Activate intuitive heuristics; 7) Contextualize linguistic input; 8) Integrate language skill; 9) Raise cultural consciousness; 10) Ensure social awareness. The macro strategic framework is open, and teachers can constantly revise their theory according to different situations in actual teaching, so as to make them develop their knowledge, skills and autonomy.

The three parameters and ten principles in the macro frameworks are intertwined to provide a dynamic, flexible and open foreign language teaching theory for foreign language teaching (Xie, 2010).

\section{OBE Theory}

In the Post-method era, a large number of new learning modes and teaching concepts have emerged, which are widely used in foreign language teaching, such as MOOC, flipped classroom, SPOC, etc. Among them, the OBE has attracted language teachers' attention and brought new ideas to foreign language teaching. OBE is the short for "Outcome-based Education". It means "starting with a clear picture of what is important for students to be able to do, then organizing the curriculum, instruction, and assessment to make sure that this learning ultimately happens." (Spady, 1994:12) It is a student-centric teaching and learning methodology in which the course design, teaching and assessment are planned to achieve stated objectives and outcomes. In terms of its concept, it reflects student-orientedness. In practice, it focuses on students' learning effect. In methodology, the curriculum design is carried out around the expected output results. OBE overcomes the deficiencies of the separation of theory and practice experienced in Chinese and English teaching. Combining theory with practice, it is, therefore, of guiding value in improving the quality of talent training and intensifying teaching reforms.

\section{Practice of OBE in Foreign Language Teaching in "Post-method" Era}

\subsection{Cultivation of teachers based on OBE}

The research on teachers aims to help teachers better understand the nature of teaching to ensure the sustainable development of teachers' profession. Post-method pedagogy emphasizes the importance of the teacher's position and values the teacher's beliefs, experiences and knowledge. 


\begin{abstract}
"Post-method" teachers are autonomous learners who should understand the essence and nature of teaching and autonomously probe for practical and effective methods and approaches based on their prior knowledge, teaching practice and experiences. The implementation of the OBE educational concept requires teachers to change from the "teacher-centered" teaching mode to the "students-centered" teaching mode, which sets higher requirements to the cultivation of university teachers (Liu \& Sun, 2017). The cultivation of university teachers based on OBE concept involves three aspects - the change of teachers' teaching concept, the improvement of teachers' professional quality, and the development of positive professional ethics, ensuring a sustainable development of teachers' profession and a constant improvement of teaching quality.
\end{abstract}

\title{
4.1.1 Change of teaching concept
}

For many years, there are continual revolutions and reforms in search for the best teaching method in language teaching. However, "a long-felt dissatisfaction with the concept of method as the organizing principle for L2 teaching and teacher education appeared in many works of language researchers" (Kumaravadivelu, 2001: 538). It is often said that there are ways for teaching, but no fixed ways always. What matters is using the right way to teach. It can be seen that a teaching method should not be regarded as a dogma, formula or procedure, nor could it be applied to all situations. Instead, it should be a flexible, individualized way that conforms to the features and law of students' learning (Yu, 2020).

Post-method pedagogy requires teachers to reflect on the limitations of the traditional teaching methods. According to the "Post-method" foreign language teaching, teachers should reform teaching methods, create micro teaching strategies and form their own language teaching theories with the consideration of their actual teaching situation. From the Post-method perspective, no excellent teaching method is available. To avoid blindly accepting the western teaching theories and methods, it is of necessity for teachers to choose and optimize the methods based on China's actual conditions and to tailor them suitable for Chinese students, making reforms and breakthroughs in the localization of foreign language teaching methods (Qi and Zhang, 2017).

OBE is an innovation of educational paradigm whose core concepts of studentscenteredness, outcome-orientedness and continual improvement are the basis for teacher to reconsider and reflect their traditional teaching concepts. OBE concentrates on answering three questions which teachers should note - "What will students learn?", "How do they learn?" and "How well do they learn?" Therefore, the whole teaching should be carried out to find answers to the questions from the perspectives of teaching plans, teaching process, evaluation and assessment. Meanwhile, teachers should also take into account teaching mode, individual differences, students' expected learning outcome and their career development as well.

\subsubsection{Change of teachers' role}

Under the concept of OBE, the roles of English teachers have gradually changed, from previous controllers to organizers, guides, promoters and participants. The relationship between teachers and students is no longer the traditional subject-object binary opposition relationship, but a balanced inter-subjectivity teaching relationship. Knowing students' ability and needs, teachers 
respect students and accept their individual differences. Teaching and learning is more like a dialogue or interactive behavior, conductive to improve students' learning effectively.

\subsubsection{Development of teacher professionalism}

Teachers' professional ability is the primary factor impacting the quality of their English teaching. Teacher professionalism refers to the improvement of teaching abilities, including the knowing of professional theories and knowledge, the capabilities of constructing curriculum, choosing teaching contents, adjusting teaching methods, acknowledging students' central roles in the learning process, making teaching reforms, and using modern educational technology. Professionalism requires teachers to enhance their academic research ability and keep continuous learning and active participation in teaching research and reform as the main way of their own professional development. The way to develop teacher professionalism includes two aspects:

First, foreign language teachers need to take part in academic training because it is an important step to develop their overall professional ability and a guarantee of good teaching effects. Universities and colleges, the main platforms for teachers' development, should give teachers guidance for their career plan and development and attach importance to teachers' professional training to enhance their ability and competitiveness. Teachers should not only be given opportunities to have academic visits at home and aboard, but also be encouraged to actively engage in scientific research activities (such as symposiums, seminars, conferences, and workshops) to lay good theoretical foundations for their teaching practice. Teachers should also make attempts to carry out professional transformations. They should be encouraged to become "double-qualified" teachers, and have access to get corresponding training, which is of great importance to meet the needs of students' professional and career development.

Second, teachers themselves should also take the initiative to carry out educational research into their teaching practice to better monitor and assess their teaching so as to make appropriate adjustments because effective professional development should be driven by real data and fieldwork and result in improved student outcomes. Through classroom observation, interviews, questionnaires, lectures and other forms of research, teachers can get the most important first-hand information about their teaching. Then, they can make reflection on their teaching and make some changes accordingly. More importantly, following a continuous process of "practice-reflection-adjustment-practice", teachers can put forward solutions to improve not only the quality of teaching, but their professionalism as well.

\subsubsection{Cultivation of teachers' professional ethics}

Teachers' professional ethics refers to the relatively stable moral concepts, behavior norms and moral qualities formed by teachers in the process of education. It is the basic requirement for teachers' professional behavior of a certain society or class (Shen, 2004). Teachers' professional ethics is directly related to the formation of teachers' quality and plays an important role in shaping students' moral quality. It defines what kind of thoughts, positions and behaviors teachers should take to regulate their relationship with other participants in the process of education ( $\mathrm{Li}, 2020)$. 
"People-orientation, love and dedication" is the general guiding ideology for the construction of teachers' professional morality in the new era. Teachers' influence on students is a crucial element going through the whole process of education. Teachers' encouragement, appreciation and love for students, as well as their enthusiasm, fairness and impartiality, selflessness, professional dedication in their career will make positive impacts on students' English learning. Students can reduce foreign language learning anxiety, gain confidence and boost interest in learning, thus improving their learning outcome. In this way, English learning is not a passive activity, but knowledge exchange and communication between teachers and students in a harmonious environment.

\subsection{Cultivation of Students based on OBE}

\subsubsection{Cultivation of active learners}

Active learning means that all students are engaged in the learning process and think about what they are doing. Different from "traditional" modes of instruction in which students passively receive knowledge from their teachers, OBE concept emphasizes students' centric position in language learning, deeming that active learners are active participants, reflectors, creators and thinkers. There is no single specific teaching method to be used in active learning situations. To make their learning sessions active, English teachers should create an "active" class for students where they are more willing to think and engage in learning with all kinds of learning activities, such as role play, group discussion, peer review and so on, freeing students from the traditional mode of receiving knowledge passively. At the same time, it is necessary to provide students with opportunities to participate in decision-making, and encourage them to make full use of learning resources so that they can acquire comprehensive abilities, including academic ability, language ability, cultural ability, and computer network technology.

\subsubsection{Cultivation of autonomous learners}

In the west, as early as more than 2,000 years ago, Socrates, Plato, Aristotle, Rousseau and other western thinkers and educators proposed the idea of autonomous learning, which has laid a solid ideological foundation for the development of autonomous learning theory and practice. Since the middle of the 20th century, the emergence of cognitivism, constructivism and humanistic psychology have provided a theoretical and practical basis for autonomous learning. From the mid-1970s on, research on autonomous learning in the west began to be systematic, with research scopes diversified and research contents detailed $(\mathrm{Gu}, 2018)$. In China, the thought of autonomous learning can be traced back to the pre Qin times when Confucius' heuristic teaching thought, Mencius' “学贵自得” (learning on one's own is the most important of all), and Cheng Yi's thought “学莫贵于自得” (Nothing is more valuable than self-teaching) were put forward, all embodying the thought of autonomous learning.

In the 1980s, Holec (1981:3) formally introduced the concept of autonomous learning into the field of language teaching; he first proposed "learner autonomy" and defined it as "the ability to take charge of one's learning". Dickinson (1995) holds that autonomous learning is both an attitude towards learning and an ability to learn independently. Autonomous learning takes students as the main body of learning who make their own decisions and are not subject to other 
people's control. The meaning of autonomous learning develops and expands constantly with the passing of the time, from the emphasis on individual independent learning to cooperative learning with others (Dickinson, 1987; Little, 1991, 1994; Dam, 1995; Littlewood, 1996), from the emphasis on autonomous learning in the classroom environment to the focus on information literacy in the network environment (Xu, 2020).

In recent years, attention has been paid to the cultivation of students' autonomous language learning ability, which is also a focus in the new round of College English curriculum reform. The Guidelines on College English Teaching issued by the China's Ministry of Education in 2015 pointed out that the teaching goal of college English is to cultivate students' English application ability, enhance their cross-cultural communication awareness and communication ability, develop their autonomous learning ability, and improve their comprehensive cultural literacy, to effectively use English in their study, life, social communication and future work, and meet the needs of the national, social, school and individual development (Wang, 2016: 5). In 2020, a new revised Guidelines on College English Teaching was completed, emphasizing the improvement in students' active learning, autonomous learning and individualized learning in the era of educational modernization. Autonomous learning is playing an important role in modern education. With the deep integration of information technology and education, the ways to acquire knowledge become more diverse. Knowledge learning has extended from traditional classroom learning to online platform learning characterized by flexibility, resourcefulness, and individualization. The new way of learning requires a high degree of learner autonomy since autonomous learning ability is one of the qualities that learners should have in the era of educational modernization.

The three parameters and ten macro principles in "Post-method" teaching provide a theoretical basis for foreign language teachers to probe into the learners' individual variations such as metacognitive, cognitive and social-affective learning strategies because learners can benefit from their proper use of strategies to improve their autonomous language learning. Eventually, with autonomous learning ability, students are able to become independent and lifelong learners, which is also in agreement with OBE talent training objectives.

\subsection{Construction of College English Teaching System based on OBE Concept}

According to Anthony (1963), a "system" refers to language teaching and learning theory based on which teachers design classroom activities. This kind of teaching system is not invariable, but dynamic, and tends to be perfected with the deepening of language research. Post-method language teaching is human-oriented, highlighting the importance of student subjectivity and autonomy, with students as the centers in teaching and learning. Establishing a "studentscentered" teaching approach based on OBE puts a high value not only on mutual understanding between teachers and students but also on their self-reflection, self-awareness and adjustment. It is advisable to construct an English teaching system based on the combination of "Post-method" theory and OBE concept, which can be listed as follows:

1) Establishing diversified English teaching modes. With the development of educational modernization, traditional teaching mode can no longer meet the need of language teaching and learning. Ubiquitous learning environment provides students and teachers 
diversified teaching and learning choices, such as blended teaching and learning, mobile learning based on We-chat APP, and other platforms like MOOC, Rain- classroom and so on.

2) Exploring interactive English teaching methods. The interactive teaching method aims at cultivating students' enthusiasm and initiative in independent learning, which fully embodies "student-centered" teaching concept. Cooperative teaching and learning method is a very good way to realize interaction between teacher and students, and between students and students.

3) Formulating multidimensional evaluation criteria. Dai (2008) pointed out that the focus of improving education quality and reforming examinations at current time is to build a scientific examination and evaluation system on the basis of traditional examination, so as to change from single evaluation to multiple ones, which is not only the core issue of examination reform, but also the key of education reform. In English teaching, teachers can also evaluate students' language performance based on their regular performance, such as in-class participation and off-class online learning. The ways to evaluate include teacher evaluation, peer evaluation and online automatic evaluation.

\section{Conclusion}

"Post-method" teaching is a new idea for foreign language teaching, which breaks through the shackles of traditional foreign language teaching methods and theories. It is flexible, dynamic and contextual in both theory and practice. "Post-method" teaching emphasizes "student's autonomy", teacher-students-students' interaction, students' individual differences in learning, and students' overall development. OBE English teaching has its advantages over the traditional teaching. It attaches importance to students' learning outcome and the multilateral interaction and collaboration among students and teachers, which is just in alignment with Post-method teaching concepts. In a word, in Post-method era, OBE, as a renovation of teaching paradigm, plays a positive role in English language education and research and in enriching the practice of talent cultivation at both theoretical and practical levels.

\section{Acknowledgements}

The work was supported by the Teaching and Research Project funded by Yangtze University in 2020 (NO. 116).

\section{Conflict of Interest Statement}

The authors declare no conflicts of interests.

\section{About the Authors}

Ma Yan, MA., Associate Professor at the School of Foreign Studies, Yangtze University, in China. Her research interests are foreign language teaching and translation studies.

Zhang Shuyue, MA., Lecturer at the School of Foreign Studies, Jingzhou College, in China. Her research interests include foreign language teaching and translation studies. 


\section{References}

Allwright, R. L. (1991). The death of the method (Working paper No. 10). English: The Exploratory Practice Center, The University of Lancaster.

Anthony, E. M. (1963). Approach, method, and technique. English Language Teaching, (17-2) : 6367.

Brown, H. D. (2002). English language teaching in the "Post-Method" era: Towards better diagnosis, treatment, and assessment. In J. C. Richards \& W. A. Renandya (Eds.), Methodology in Language Teaching. Cambridge: Cambridge University Press, 9-18.

Dai, J. G. (2008). Reform Our Exams. Beijing: Higher Education Press.

Dam, L. (1995). Learner Autonomy: From Theory to Classroom Practice. Dublin: Authentik.

Dickinson, L. (1987). Self-Instruction in Language Learning. Cambridge: Cambridge University Press.

Dickinson, L. (1995). Autonomy and motivation: a literature review. System, 23, (02): 165-174.

Gu, S. M. (2018). Theoretical and practical research on college English autonomous learning: gains and losses. Heilongjiang Researches on Higher Education, 36(05): 42-46.

Holec, H. (1981). Autonomy and Foreign Language Learning. Oxford: Pergamon Press.

Kumaravadivelu, B. (2003). Beyond Methods: Macro-strategies for Language Teaching. New Haven: Yale University.

Kumaravadivelu, B. (2001). Toward a Post-method pedagogy. TESOL Quarterly, (12): 537-560.

Li, J. and Cai, J. (2020). On teachers' professional ethics in the new era. Journal of Changchun Normal University, 39(09), 132-134.

Little, D. (1994). Learner autonomy: a theoretical construct and its practical application. Die Neueren Sprachen, 93(5), 430-442.

Little, D. (1991). Learner Autonomy: Definitions, Issues and Problems. Dublin: Authentik.

Littlewood, W. (1996). Autonomy: an anatomy and a framework. System, 24(4): 427-435.

Liu, X. D. (2008). The origin of Postmethod. Jiangsu Foreign Language Teaching and Research, (01): $1-5$.

Liu, K. and Sun, Y. F. (2017). Research on the cultivation of university teachers based on OBE educational concept. Heilongjiang Researches on Higher Education, (6): 59-61.

Qi, F. and Zhang, J. (2017). Reflections on ELT Macro-strategies and Micro-techniques in "Postmethod" Era China. Foreign Language Education, 38, (05): 54-59.

Rao, X. F. and Ji, P. (2014). The Postmethod perspective and college English teaching and learning in the era of globalization. Journal of Tianjin Foreign Studies University, 21(03): pp. 46-53.

Shen, J. L. and Zhao, J. X. (2006). A reflection of professional morals and ethics of primary and secondary school teachers. Journal of Beijing Normal University (Social Sciences), (1):48-55.

Spady, W. G. (1994). Outcome-based Education, Critical issues and Answers. Arlington: American Association of School Administrators.

Wang, S. R. (2016). An interpretation of the guidelines on college English teaching. Foreign Language World, (03): 2-10.

Xie, X. C. (2010). On the teaching framework of CET in the Post-method era. Journal of Guangdong University of Foreign Studies, (1): 96-99. 
Xu, J. F. (2020). Autonomous learning ability of foreign language majors and its cultivation. Foreign Language World, (06): 26-32+62.

$\mathrm{Yu}$, H. L. (2020). Implementing the College English Teaching Guidelines to reform teaching methods and teaching means. Foreign Language World, (05): 10-16.

Author(s) will retain the copyright of their published articles agreeing that a Creative Commons Attribution 4.0 International License (CC BY 4.0) terms will be applied to their work. Under the terms of this license, no permission is required from the author(s) or publisher for members of the community to copy, distribute, transmit or adapt the article content, providing a proper, prominent and unambiguous attribution to the authors in a manner that makes clear that the materials are being reused under permission of a Creative Commons License. Views, opinions and conclusions expressed in this research article are views, opinions and conclusions of the author(s). and European Journal of Literature, Language and Linguistics Studies shall not be responsible or answerable for any loss, damage or liability caused in relation to/arising out of conflicts of interest, copyright violations and inappropriate or inaccurate use of any kind content related or integrated into the research work. All the published works are meeting the Open Access Publishing requirements and can be freely accessed, shared, modified, distributed and used in educational, commercial and non-commercial purposes under a Creative Commons Attribution 4.0 International License (CC BY 4.0). 